\title{
HUBUNGAN DEPRESI POST PARTUM TERHADAP PENGELUARAN ASI DI RUMAH SAKIT IBU DAN ANAK CEMPAKA PUTIH SURABAYA
}

\author{
Relationship of Postpartum Depression Toward Milk Expenditure in Hospital of Women \\ and Children Cempaka Putih Surabaya
}

\author{
Anik Latifah ${ }^{1}$ \\ 1. Universitas PGRI Adi Buana Surabaya
}

\author{
Riwayat artikel \\ Diajukan: September 2020 \\ Diterima: Maret 2021.
}

\section{PenulisKorespondensi: \\ - Anik Latifah \\ - Universitas PGRI Adi Buana Surabaya \\ - aniklatifah@unipasby. ac.id}

\section{Kata Kunci: \\ Depresi, Postpartum, Pengeluaran ASI}

\begin{abstract}
Abstrak
Melahirkan dan merawat anak merupakan suatu peristiwa yang membahagiakan buat seorang wanita. Tetapi untuk beberapa wanita hal ini merupakan kondisi baru dalam fase kehidupannya, dimana wanita tersebut harus mampu menyesuaikan kondisi yang dialami. Sebagian wanita berhasil menyesuaikan peran dan aktifitas barunya namun sebagian lainnya kurang berhasil melakukan penyesuaian diri dengan baik. Angka kematian ibu dan bayi merupakan indikator penting dalam mengukur derajat kesehatan negara. Berdasarkan hasil survei penduduk tahun 2015. AKI di indonesia masih tinggi, yaitu sebesar 305/100.000 kelahiran hidup (KH) sedangkan ditahun 2017 target 126/100.000 masih belum tercapai. Sedangkan AKB menurut survei demografi kesehatan indonesia (SDKI) 2015 adalah 24/1000 KH, angka ini menyumbangkan angka terbesar angka kematian bayi, ditahun 2017 turun menjadi 22/1000 KH. Tujuan penelitian ini untuk mengetahui hubungan depresi post partum terhadap pengeluaran asi di rumah sakit ibu dan anak cempaka putih surabaya. Jenis penelitian ini adalah penelitian kuantitatif dengan pendekatan cross sectional di mana pengukuran variabelnya dilakukan hanya satu kali. Dari 15 sampel yang diambil didapatkan hasil 9 responden $(60 \%)$ tidak mengalami resiko depresi, sebagian besar usia responden 20-35 tahun sebanyak 12 responden $(80 \%)$, sebagian besar berpendidikan tinggi sebanyak 9 responden $(60 \%)$ sebagian besar sudah keluar ASI dalam waktu 48 jam sebanyak 12 responden $(80 \%)$ hasil analisis uji statistic pearson correlation didapatkan nilai $P$ Value (Asymp.Sig2 Tailed) sebesar 0,621 dimana lebih dari batas kritis penelitian 0,05.
\end{abstract}

\section{Abstract}

Giving birth and caring for children is a happy event for a woman. But for some women this is a new condition in their life phase, where the woman must be able to adjust the conditions experienced. Some women are successful in adapting to their new roles and activities, but others are less successful in adapting themselves properly. Maternal and infant mortality rates are important indicators in measuring the health status of a country. Based on the results of the 2015 population survey, MMR in Indonesia is still high, namely 305 / 100,000 live births (KH), while in 2017 the target of 126 / 100,000 has not been achieved. Meanwhile, the IMR according to the 2015 Indonesian Health Demographic Survey (IDHS) is 24/1000 KH, this figure contributes to the largest number of infant mortality rates, in 2017 it fell to 22/1000 KH. The purpose of this study was to determine the relationship between postpartum depression and breastfeeding expenditure at the Cempaka Putih Hospital, Surabaya. This type of research is a quantitative study with a cross- sectional approach where the measurement of the variable is carried out only once. From 15 samples taken, the results obtained 9 respondents (60\%) do not experience the risk of depression, most of the respondents aged 20-35 years as many as 12 respondents (80\%), most of them are highly educated as many as 9 respondents (60\%), most of them have been out of ASI within 48 hours as many as 12 respondents (80\%) the results of the pearson correlation statistical test analysis obtained a P-Value (Asymp.Sig2 Tailed) of 0.621 which is more than the critical research limit of 0.05 . 


\section{Pendahuluan}

Melahirkan dan merawat anak merupakan suatu peristiwa yang membahagiakan buat seorang wanita. Tetapi untuk beberapa wanita hal ini merupakan kondisi baru dalam fase kehidupannya, di mana wanita tersebut harus mampu menyesuaikan kondisi yang dialami. Sebagian wanita berhasil menyesuaikan peran dan aktifitas barunya namun sebagian lainnya kurang berhasil melakukan penyesuaian diri dengan baik. Angka kematian ibu dan bayi merupakan indikator penting dalam mengukur derajat kesehatan negara.

Berdasarkan hasil survei penduduk tahun 2015, AKI di Indonesia masih tinggi, yaitu sebesar 305/100.000 kelahiran hidup (kh). Sedangkan ditahun 2017 target 126/100.000 masih belum tercapai. Sedangkan AKB menurut Survei Demografi Kesehatan Indonesia (SDKI) 2015 adalah 24/1000 kh, angka ini menyumbangkan angka terbesar angka kematian bayi . Ditahun 2017 turun menjadi 22/1000 kh.

Mengacu pada tujuan MDGs di mana tercapai kesejahteraan rakyat dan pembangunan masyarakat 2015, dari delapan butir, tujuan kelima adalah meningkatkan kesehatan ibu dengan target menurunkan angka kematian ibu sebesar tiga perempatnya 1990- 2015 serta yang menjadi indikator untuk monitoring yaitu angka kematian ibu. AKI merupakan indikator dasar pelayanan kesehatan terhadap wanita usia reproduktif. Data WHO memperkirakan 585.000 perempuan meninggal setiap harinya akibat komplikasi kehamilan, proses kelahiran, dan aborsi yang tidak aman akibat kehamilan yang tidak diinginkan. Diperkirakan 99\% kematiantersebut terjadi di negara negara berkembang (WHO,2007).

Menurut organisasi kesehatan di dunia ada lebih dari 100 juta orang di dunia yang mengalami depresi, namun kurang dari $25 \%$ diantaranya yang pernah menerimapengobatan. Dari hasil penelitian yang pernah dilakukan oleh Irawati dan Yuliani (2014) di RSUD Basuni Mojokerto didapatkan bahwa dari 37 responden ada sebanyak $59,5 \%$ mengalami postpartum blues dengan menggunakan EPDS (Edinburgh Postnatal Depression Scale). Penelitian oleh Ayu (2015) Puskesmas Yogyakarta dari 80 responden didapatkan 37 orang (46\%) mengalami postpartum blues.

Diperkirakan tahun 2020, depresi akan menjadi kondisi medis terpenting kedua di dunia setelah masalah jantung. Periode postpartum merupakan situasi krisis bagi ibu, pasangan, dan keluarga akibat berbagai perubahan yang terjadi baik secara fisik, psikologis, maupun struktur keluarga yang memerlukan proses adaptasi atau penyesuaian. Proses adaptasi psikologi pada seorang ibu sudah dimulai sejak dia hamil. Kehamilan dan persalinan merupakan peristiwa yang normal terjadi dalam hidup, namun banyak ibu mengalami stres yang signifikan. Ada kalanya ibu mengalami perasaan sedih berkaitan dengan bayinya, keadaan ini merupakan kondisi depresi postpartum yang dialami oleh seorang ibu. Melihat dampak dari postpartum blues peneliti ingin meneliti tentang "hubungan depresi postpartum terhadap pengeluaran asi colostrum di rumah sakit ibu dan anak cempaka putih Surabaya".

\section{Metodologi}

Jenis penelitian ini adalah penelitian kuantitatif dengan pendekatan cross sectional di mana pengukuran variabel variabelnya dilakukan hanya satu kali. Peneliti mencari hubungan antara variabel bebas depresi ibu postpartum dengan variabel tergantung asi (colostrum) dengan melakukan sesaat atau dalam waktu 48 jam setelah melahirkan (Sastroasmoro, Sudigdo dan Ismael, Sofyan, 2014). Penelitian ini dilakukan di Rumah Sakit Ibu dan Anak Cempaka Putih Surabaya. Periode Februari Agustus 2020. Populasi pada penelitian ini adalah semua wanita setelah 
melahirkan di Rumah Sakit Cempaka Putih Surabaya. Sampel pada penelitian ini adalah wanita setelah melahirkan yang mengalami depresi di Rumah Sakit Cempaka Putih Surabaya. Pemilihan sampel dalam penelitian ini menggunakan consecutive sampling (Sastroasmoro, Sudigdo dan IsmaelSofyan 2014). Kriteria inklusi responden dalam penelitian ini adalah: Ibu postpartum yang mengalami depresi. Sampling dalam penelitian ini adalah sebesar 15 orang. Instrumen penelitian menggunakan kuesionerstandar WHO Eidenbergh Postpartum Depression Scale (EPDS).

\section{Hasil dan Pembahasan}

Tabel 1. Distribusi frekuensi tingkat depresi pada ibu nifas

\begin{tabular}{|c|c|c|c|}
\hline NO & Depresi & $\Sigma$ & $\%$ \\
\hline 1 & Depresi Berat & 2 & 13,3 \\
\hline 2 & $\begin{array}{l}\text { Depresi } \\
\text { Sedang }\end{array}$ & 4 & 26,7 \\
\hline 3 & Tidak beresik & 9 & 60 \\
\hline & Total & 15 & 100 \\
\hline
\end{tabular}

Pada tabel 1 didapatkan bahwa sebagian besar tidak mengalami resiko depresisebanyak 9 responden $(60 \%)$. sedangkan sebagian kecil depresi berat didapatkan sebanyak 2 responden (13,3 $\%)$.

Tabel 2. Disribusi umur responden

\begin{tabular}{llll}
\hline NO & Karakteristik usia & $\Sigma$ & $\%$ \\
\hline 1 & $<20$ th & 0 & 0 \\
2 & $20-35$ & 12 & 80 \\
3 & $>35$ & 3 & 20 \\
\hline & Total & 15 & 100 \\
\hline
\end{tabular}

Pada tabel 2 didapatkan hasil bahwasebagian besar usia responden 2035 tahun sebanyak 12 responden $(80 \%)$ sedangkan sebagian kecil diatas 35 tahun sebanya 3 responden $(20 \%)$

Table 3. Distribusi responden bersadarkan Pendidikan

\begin{tabular}{llcl}
\hline NO & Pendididkan & $\Sigma$ & $\%$ \\
\hline 1 & PT & 9 & 60 \\
2 & SMU/Sederajat & 6 & 40 \\
\hline & Total & 15 & 100
\end{tabular}

Pada tabel 3 didapatkan hasil bahwa sebagian besar berpendidikan tinggi sebanyak9 responden $(60 \%)$.

Tabel 4. Distribusi responden berdasarkan pengeluaran ASI

\begin{tabular}{|c|c|c|c|}
\hline $\mathrm{NO}$ & ASI & $\Sigma$ & $\%$ \\
\hline 1 & $\begin{array}{l}\text { Tidak keluar } \\
\text { ASI dalam } \\
48 \text { jam }\end{array}$ & 3 & 20 \\
\hline \multirow[t]{2}{*}{2} & $\begin{array}{l}\text { Keluar ASI } \\
\text { dalam } 48 \text { jam }\end{array}$ & 12 & 80 \\
\hline & Total & 15 & 100 \\
\hline
\end{tabular}

Pada tabel 4 didapatkan hasil bahwa sebagian besar sudah keluar ASI dalam waktu 48 jam sebanyak 12 responden $(80 \%)$.

Tabel 5. Hubungan DPP dengan ASI

\begin{tabular}{llll}
\hline N0 & $\begin{array}{l}\text { Variabel } \\
\text { Dependen }\end{array}$ & $\begin{array}{l}\text { Variabel } \\
\text { Independen }\end{array}$ & Sig \\
\hline 1 & Depresi & ASI & 0,621 \\
& PostPartu & & \\
& m & &
\end{tabular}

(DPP)

Berdasarkan tabel 5 hasil analisa statistik dengan menggunakan uji pearson correlation dengan SPSS 21 mengetahui hubungan tingkat depresi postpartum dengan pengeluaran ASI pada ibu nifas di RumahSakit Ibu dan Anak Cempaka putih Surabaya didapatkan nilai P-Value (Asymp.Sig2 Tailed) sebesar 0,621.

Berdasarkan tabel 1 mengenai distribusi frekuensi tingkat depresi pada ibu nifas di Rumah Sakit Ibu dan Anak Cempaka Putih Surabaya didapatkan bahwa sebagian besar tidak beresiko depresi sebanyak 9 responden $(60 \%)$ dan sebagian kecil mengalami depresi berat sebanyak 2 responden (13,3\%).

Dalam penelitian lain menjelaskan bahwa ada hubungan depresi dengan kelancaran ASI pada ibu menyusui (Amalia,2016). Penjelasan Amalia mengindikasikan bahwa ASI yang tidak lancar dapat menyebabkan kejadian postpartum blues maupun sebaliknya menyebabkan terganggunya produksi ASI. Menurut peneliti perbedaan tingkat 
depresi pada ibu nifas disebabkan karena perbedaan respon atau mekanisme koping yang dimiliki oleh masing masing ibu. Pada ibu setelah melahirkan banyak faktor yang menjadi pemicu terjadinya depresi, adanya perasaan tidak nyaman, kelelahan, ketidak tahuan tentang merawat bayi, adanya dukungan keluarga, harapan terhadap kelahiran bayi, temperamen ibu, karakteristik bayi, kondisi yang tidak terduga berkaitan dengan proses persalinan. Depresi postpartum biasanya juga disebut sebagai postpartum blues yang mana merupakan suatu sindrom gangguan efek yang ringan sering tampak dalam minggu pertama setelah persalinan cenderung akan memburuk pada hari ketiga sampai kelima dalam rentang waktu 14 hari atau dua minggu postpartum. Depresi postpartum dapat menganggu keharmonisan pasangan suami istri serta menimbulkan perasaan yang tidak nyaman bagi ibu yang mengalaminya (Susanti,2018).

Adapun faktor yang mempengaruhikondisi psikologis ibu juga bisa dipengaruhi oleh usia, berdasarkan tabel 2 didapatkan bahwa di Rumah Sakit Ibu dan Anak Cempaka Putih Surabaya usia 20-35 tahun didapatkan 12 responden $(80 \%)$, sedangkan usia $>35$ tahun 3 responden (20\%). Menurut peneliti usia 20-35 tahun juga dapat mengalami depresi postpartum dikarenakan banyak faktor tetapi disisi lain usia 20-35 tahun merupakan usia yang matang atau pas dalam bereproduksi, menurut pengamatan peneliti hal ini juga diikuti oleh kematangan secara psikologis mengingat diusia tersebut sudah termasuk dalam golongan usia matang. Sehingga dalam penelitian ini lebih sedikit ibu yang mengalami depresi. Selain itu koping emosi diusia tersebut dapat diminimalisir seiring bertambahnya usia. Menurut Saifudin (2011) kelancaran ASI dipengaruhi olehbeberapa faktor antara lain makanan,ketenangan jiwa, perawatan payudara,penggunaan alat kontrasepsi, anatomis payudara dan pola istirahat. Jika dilihat dari teori Saifudin usia tidak masuk dalam faktor yang mempengaruhi kondisi kelancaran ASI. Faktor kedua kondisi yang dapat mempengaruhi psikologis ibu yaitu pendidikan berdasarkan tabel 3 didapatkan, dari 15 responden sebagian besar telah lulus dari perguruan tinggi sebanyak 9 orang (60\%), sedangkan 6 orang $(40 \%)$ berpendidikan sederajat SMU, hal ini menandakan bahwa pendidikan juga sangat berpengaruh dalam hal kematangan psikologis. Pada penelitian ini didapatkan banyak lulusannya perguruan tinggi, sehingga ibu ibu tersebut mudah menerima informasi yang didapatkan dan mampu mengaplikasikannya. Bukan hanya itu saja mereka juga mampu untuk mencari informasi dimedia sosial tentang persiapan apa saja yang harus dilakukan pada saat setelah melahirkan.

Berdasarkan hasil yang diperoleh pada tabel 4 ibu nifas hari kedua ASI nya sudah keluar didapatkan 12 responden (80 $\%), 3$ responden $(20 \%)$ mengalami ASI belum keluar. ASI keluar atau tidak, dipengaruhi beberapa faktor diantaranya ibu merasa tidak nyaman dengan keadaanya menurut (Suherni, 2008). Menurut peneliti hal ini menunjukan bahwa kondisi psikologis ibu yang baik akan memotivasi untuk menyusui bayinya sehingga hormon yang berperan pada produksi ASI akan meningkat. karena produksi ASI dimulai dari proses menyusui. Dalam penelitian yang dilakukan di Rumah Sakit Ibu dan Anak Cempaka Putih Surabaya didapatkan sebagian besar ASI sudah keluar. Berdasarkan hasil perhitungan dengan menggunakan uji koefisien korelasi spearman diketahui bahwa $P$ value A sym 2 Tailed $=0,621 \quad(>0,05)$ sehingga diketahui tidak adanya hubungan antara depresi postpartum terhadap pengeluaran ASI. Ibu yang setelah melahirkan harus berfikir positif, berusaha mencintai bayinya. Ketika berfikir positif dan tenang maka ASI bisa keluar dengan lancar. 


\begin{abstract}
Sebaliknya ibu yang kondisi psikologisnya terganggu akan mempengaruhi produksi ASI bisa menurun hingga menyebabkan keterlambatan pengeluaran ASI. Dari ulasan antara teori dan hasil yang didapatkan oleh peneliti bahwa tidak sesuai dengan teori, banyak teori dan hasil penelitian yang lain mengatakan bahwa depresi dapat mempengaruhi pengeluaran ASI, dalam hal ini banyak faktor yang mempengaruhi pengeluran ASI selain faktor stress juga makanan. Artinya ketika ibu mengalami depresi tapi ternyata nafsu makan tidak berpengaruh maka produksi ASI masih bisa berproduksi dengan baik. Selain itu faktor keterbatasan peneliti berinteraksi dengan pasien juga bisa mempengaruhi, barangkali dalam hal melakukan penelitian ada hal hal yang kurang diketahui oleh peneliti sehingga apa yang didapatkan tidak sesuai dengan teoriatau hasil peneliti orang lain.
\end{abstract}

\section{Simpulan}

Sebagian besar ibu nifas di rumah sakit ibu dan anak cempaka putih Surabaya mengalami tidak beresiko sebanyak 9 responden $(60 \%)$. Sebagian besar ibu yang melahirkan di Rumah Sakit Ibu dan Anak Cempaka putih berusia 20-35 tahun sebanyak 12 responden (80\%). Sebagian besar responden berpendidikan tinggi didapatkan 9 responden (60\%), sebagian besar ibu nifas di Rumah Sakit Ibu dan Anak Cempaka Putih mengalami ASI sudah keluar dalam waktu 48 jam didapatkan sebanyak 12 orang (80\%).Tidak Adanya hubungan depresi postpartum terhadap pengeluaran ASI ibu di rumah sakit ibu dan anak cempaka putih Surabaya ditunjukan dari hasil Uji Spearmen p-value (Asymp.sig 2 Tailed) sebesar 0,621 (>0,05).

\section{Daftar Pustaka}

Amalia R,R.,(2016). Peran Dukungan Suami Terhadap Kondisi Depresi Post Partum. Surabaya
Azwar, Saifuddin. 2011. Metode Penelitian. Yogyakarta: Pustaka Pelajar.

Downie,J.,Wynaden,D.,Mcgowan,S.,Juliff,D. ,Axten,C.,Fitzpatrick,L.,Ogilvie,S.,\&

Painter, S(2003). Using The Edinburgh Posnatal Depression Scale To Achieve Best Practice Standarts. Nursing And Healtahunsciences,5 283287Https://Www.Google.Com/Sea rch?Safe $=$ Strict $\& Q=$ Sdki+2017+Tenta ng+Aki\&Sa=X\&Ved=2ahukewjuovk dttxoahv56xmbhyhfb4cq1qiobx

Oecasqbg Livana, P. H., Susanti, Y., Darwati, L. E., \&

Anggraeni, R. (2018). Gambaran Tingkat Depresi Lansia. NURSCOPE

J. Keperawatan Dan Pemikir. Ilm, 4(4), 80-93.

Nevid,Rathus \& Greene. (2005).Psikologi Abnormal, Jilid 1.Alih Bahasa, Tim Psikologi UI. Jakarta: Erlangga

Oktavia \& Basri. (2002).Hubungan DukunganSosial Yang Diterima Secara Nyata Dengan Ada/Tidaknya Gangguan Depresi Pasca Persalinan Pada Ibu Dewasa Muda.Jurnal Psikologi Sosial Vol 8 N0.1 15-22

Sastroasmoro,Sudigdo \&Ismael,Sofyan. 2014. Dasar Dasar Metodologi Penelitian Klinis Edisi Ke 5. Jakarta: Sagung Seto.

Niswati, Amalia Fahri, Dewi Kartika Sari, And Sri Hartutik. Hubungan Pola Komunikasi Keluarga Dengan Mekanisme Koping Pada Lansia Depresi Di Posyandu Sari Waluyo Wilayah Kerja Puskesmas Gambirsari Surakarta. Diss. Stikes'aisyiyah Surakarta, 2018. 